\title{
Can Universities Close the Gender Gap? Exploring and Measuring the Gender Gap in Romanian Higher Education
}

\author{
Anca Gabriela Ilie ${ }^{1}$, Dan Dumitriu ${ }^{2}$ and Roxana Sarbu ${ }^{3}$ \\ ${ }^{1,2}$ The Academy of Economic Studies, Faculty of International Business and Economics,Bucharest, \\ Romania \\ ${ }^{3}$ The Academy of Economic Studies, Faculty of Commerce, Bucharest, Romania
}

Correspondence should be addressed to: Anca Gabriela Ilie; ancaionescu2003@yahoo.com

Received date: 21 April 2014; Accepted date: 26 June 2014; Published date: 31 December 2014

Copyright @ 2014 . Anca Gabriela Ilie, Dan Dumitriu and Roxana Sarbu . Distributed under Creative Commons CC-BY 3.0

\begin{abstract}
This article focuses on gender gap in leadership by exploring the women experience in attaining as effective in top leadership positions. The present research paper constitutes a correlational study whose main objective is the identification of aspects pertaining to discrimination, as well as to the barriers that females are confronted with the moment they decide to pursue an academic career in Romania. The authors have applied several research methods using both documentation and quantitative and qualitative methods. Although the present qualitative study cannot be considered representative for the entire Romanian academic environment, it helps to identify a direction to be followed, it helps to form an image of the existence of gender equality and equality of opportunities in gaining access to leadership positions in universities. Our work is mainly conceived as a theoretical research grounded on statistical data. Some studies are focused on comparing the situation, adopted measures and results in different universities, with the aim to identify some common elements that can be benchmarks of good practice in the field of measuring the gender gaps. The rankings are designed to create greater awareness among a global audience of the challenges posed by gender gaps and the opportunities created by reducing them. The methodology and quantitative analysis behind the rankings are intended to serve as a basis for designing effective measures for reducing gender gaps.
\end{abstract}

Keywords: Gender equality, discrimination, gender gap, leadership, higher education, universities, Romania

\section{Introduction}

The key for the future of any country and any institution is the capability to develop, retain and attract the best talent. Women make up one half of the world's human capital.
Empowering and educating women and leveraging their talent and leadership fully in the global economy, politics and society are thus fundamental elements of succeeding and prospering in an ever more competitive world. In particular, with talent shortages projected 
to become more severe in much of the developed and developing world, maximizing access to female talent is a strategic imperative for business.( The Global Gender Gap Report, 2012)

The present paper has been written in the context of a global economic slowdown caused by the financial crisis, with negative repercussions on growth and employment in the EU. In order to combat the economic recession, it is more important than ever to invest in human capital and social infrastructure, allowing both men and women to accomplish their full potential. The equality of chances between men and women represents a key factor and a necessary contribution to a firm stance of the European Commission on the shortage of work force and the necessity of new qualifications (European Commission, 2010). Nowadays, women represent around $60 \%$ of the total number of university graduates in the EU, although their percentage in science and technology degrees remains low. However, there still exist obstacles preventing women from using their full potential and having access to the employment they are qualified for.

The equality of chances, a fundamental political value of the EU has been applied in all member states by means of various directives or strategic priorities, representing an essential means of, preparing and implementing public policies (European Commission, 2010). Gender equality also has to do with the quality of our activities as the country's foremost institution for research, education and dissemination, and the opportunities to achieve broad-ranging and good recruitment of competent personnel. "An internationally leading university must conduct an active policy of equality between women and men and a recruiting policy that results in diversity and that ensures equal rights." (Gender Equality Action Plan, 20112012)

In Romanian universities, gender equality and the equality of chances will lead to an increase in the percentage of women in academic leadership position, to a better established balance between men and women according to selected curricula, and to a stronger emphasis on an organizational culture based on the recruitment of competent personnel, thus giving both men and women equal chances to access leadership positions in the management of universities (Manolescu et al., 2012). The recruitment procedure has been improved and despite extremely rigorous requirements for promotion, there are many female applicants aiming to occupy either a position of university professor or reader or a leadership position within the University where she works. Like many other European universities, Romanian universities are facing a change in generations, and relatively many new hires are expected during the coming decade. Exploitation of this opportunity to promote gender equality depends on the number of academic positions being maintained at the same level as today as a minimum, and that managers at all levels are under an obligation to promote women's opportunities through open position announcements, encouragement of female applicants, and selection and favorization of qualified women through moderate gender quotas. (Gender Equality Action Plan, 2010-2012)

\section{Literature review}

In the specialized literature, it is said that equal performance-related employment opportunities for people are necessary, legally and socially, while preferential treatment only leads to the creation and expansion of injustice. In the following sections of the present paper, we shall put forward aspects pertaining to discrimination, as well as barriers that females are supposed to overcome the moment they decide to pursue an academic career. Ward and Wolf-Wendel (2004) believe that higher education lacks a strong tradition related to positively responding to the needs of employees. Taking into account the fact that the number of women working in this domain used to be limited, nowadays that women have made their way to the academic career, it is important to understand the institutional barriers they come up against and the challenges that mothers face when they try to achieve a balance between their work and their family (Ward and Wolf-Wendel, 2004).

In the specialized literature, there are two approaches dealing with the situation of women in higher education: the feminist one, which criticizes the by-laws of academic 
institutions (universities are considered "greedy institutions" - Coser 1974) and an approach oriented towards solving the "commitment conflicts" (Townsend and Turner, 2001).

The first approach claims that "the ideal employee" should be married to their work (Williams, 2000), while higher education is an appropriate environment for men in particular, since it requires the absence of other responsibilities, such as a family (Ward and Bensimon, 2003). According to Grant (2000), for women, the combination between work and family may represent a further disadvantage because, on the one hand, women's parenting skills are compared to those of men while on the other hand, when women choose to direct their efforts towards the academic life, their parenting skills may suffer. If, for women, this has a negative impact on the productivity of research (Snert and Holton, 1995), the same is not true for men (Bellas and Toutkoushian, 1999).

The second approach is more optimistic, claiming that, for women, family and work may complete each other (Ropers - Huilman, 2000), although major tensions may arise the moment this combination is attempted.

A very important sequel to research in this area comes from analysing this barrier in the organizational context (Ward and Wolf Wendel, 2006). As a consequence of qualitative interview-based research, the two authors have reached the conclusion that life is not experienced in a similar manner in all types of universities. If research-oriented universities mostly lack policies supporting women in this respect, (although women working in these universities have taken the job requirements as such), comprehensive, prestigious universities have much higher standards, since an employee is expected to be equally productive in their teaching activities, in their research activities and in providing specific services. In order to obtain a promotion, a member of staff has to be a fulltime employee, to have had a steady trajectory in their career and to be active in the domain of research (Carrington and Pratt, 2003).

Bagihole (2002) highlights the invisible barriers that arise at the moment of promotion in the UK academic environment: professional autonomy, culture, isolation and defective department management. If women wish to accede to leadership position in universities, they have to change their style, which means that it is not universities who make a mistake by choosing the wrong candidate, it is women who make a mistake by failing to adapt to a male leadership style. Since women's leadership style is a transformational one (Doherty and Manfredi, 2006), they have no chances of promotion, especially if there is a tendency to elect people similar to the employer.

The Global Gender Gap Report (2012) provides a comprehensive overview of current performance and progress over the last six years. On average, over $96 \%$ of the gap in health outcomes, $93 \%$ of the gap in educational attainment, $60 \%$ of the gap in economic participation and $20 \%$ of the gap in political empowerment has been closed. No country in the world has achieved gender equality. The four highest ranked countriesIceland, Finland, Norway and Sweden-have closed between 80 and $86 \%$ of their gender gaps, while the lowest ranked countryYemen - has closed a little over half of its gender gap.

\section{Research Methodology}

In order to write the present paper, the authors have turned to several research methods, using on the one hand documentation, on the other hand quantitative and qualitative methods.

At an international level, to establish the sample of analysed universities, we have taken into account the classification made by the Times Higher Education World University 2011 - 2012, including 13 performance indicators from 5 thematic areas: teaching activities work environment (30\%), research - volumes, revenues, reputation (30\%), number of citations - influence of citation (30\%), revenues from achievements - revenues, innovations $(2.5 \%)$, international perspective - students, professors and research (7.5\%). The indicators were calculated so that universities with completely different profiles may be comparable, with a view to a clear assessment of performance. 
This top ranks 400 universities at an international level; however, a public classification according to the points they have gathered only exists for the first 200. The sample has been statistically determined by the "random step" method, a "5 step" was used; thus, 40 universities were selected. The positions taken into consideration were those of President of Senate, Rector and Vice-
Rectors. In most cases the Rector occupies an honorary position, while the President of Senate and the Vice-Rectors play an executive role implementing the policies established in the Senate.

Among existing Romanian universities, we have selected the first 12 as a sample, those belonging to the category advanced research and education.

Table 1: Romanian Ranking Universities

\begin{tabular}{|c|c|c|c|c|c|c|}
\hline Ranking & $\begin{array}{l}\text { World } \\
\text { Rank }\end{array}$ & University & Presence Rank* & Impact Rank* & $\begin{array}{l}\text { Openness } \\
\text { Rank* }\end{array}$ & $\begin{array}{l}\text { Excellence } \\
\text { Rank* }\end{array}$ \\
\hline 1 & 490 & $\begin{array}{l}\text { University Politechnica } \\
\text { of Bucharest }\end{array}$ & 932 & 212 & 826 & 1235 \\
\hline 2 & 789 & $\begin{array}{l}\text { Alexandru Ioan Cuza } \\
\text { University }\end{array}$ & 2053 & 1073 & 353 & 1329 \\
\hline 3 & 825 & $\begin{array}{l}\text { Bucharest Academy of } \\
\text { Economic Studies }\end{array}$ & 1635 & 627 & 351 & 2321 \\
\hline 4 & 922 & University of Bucharest & 3115 & 1243 & 679 & 1073 \\
\hline 5 & 1198 & $\begin{array}{l}\text { University of Medicine } \\
\text { and Pharmacy Iuliu } \\
\text { Hatieganu Cluj Napoca }\end{array}$ & 5241 & 849 & 1046 & 2032 \\
\hline 6 & 1248 & $\begin{array}{l}\text { Gheorghe Asachi } \\
\text { Technical University }\end{array}$ & 1669 & 2692 & 853 & 1329 \\
\hline 7 & 1319 & $\begin{array}{l}\text { University Politechnica } \\
\text { Timisoara }\end{array}$ & 3481 & 2229 & 582 & 1631 \\
\hline 8 & 1322 & $\begin{array}{l}\text { Dunarea de Jos Universi } \\
\text { Galati }\end{array}$ & 3838 & 1552 & 489 & 2297 \\
\hline 9 & 1441 & University of Craiova & 1860 & 3729 & 344 & 1875 \\
\hline 10 & 1524 & $\begin{array}{l}\text { West University of } \\
\text { Timisoara }\end{array}$ & 3464 & 2894 & 814 & 1753 \\
\hline 11 & 1675 & $\begin{array}{l}\text { Technical University of } \\
\text { Cluj Napoca }\end{array}$ & 3820 & 3476 & 913 & 1725 \\
\hline 12 & 1684 & University Babes Bolyail & 815 & 1291 & 10219 & 867 \\
\hline
\end{tabular}

Source: authors' compilation, based on http://www.webometrics.info/en/Europe/Romania, 2012

The qualitative research consisted in conducting an interview with people in leadership positions in universities. The interview includes a set of 15 open questions, while the methods applied included an interviewer (who used a voice recorder) and a written answer to these questions. 10 people holding management positions at departmental, Faculty or University level agreed to answer these questions.
The questions referred to the following subjects: difficulties that women face when they try to occupy a leadership position, barriers they have to overcome, the existence of gender discrimination in the University they work for and in Romanian universities generally; the recommendation of measures aiming to ensure the existence of equal opportunities in promoting to leadership positions. 


\section{Research Results}

At an international level, the percentage of males who occupy the position of President of Senate is $94.59 \%$ (35 people out of 37 ); $84.85 \%$ are Rectors and $71.14 \%$ are ViceRectors. Although the percentage of women in leadership positions in universities is on the increase, to the extent to which we go down the hierarchy, it remains rather low (only $28.86 \%$ ). We can state that the results are in accordance with the specialized literature which indicates that, in prestigious universities, women's access to leadership positions is much more difficult, because of the requirements related to time, total commitment and high research standards (Wolf-Wendel and Ward, 2006).

As far as the analysis taking into account the "country" variable is concerned, related to the sample universities, the situation is similar; details can be found in the table below. For the countries which are most present in this sample (the USA and the UK), the percentage of women holding the Vice-Rector position is rather low: $33.73 \%$ and $22.81 \%$ respectively.

Table 2: Females occupying leadership positions in the Universities in Top 200

\begin{tabular}{|c|c|c|c|c|c|}
\hline Country & Number universitie & President & Rector & \multicolumn{2}{|c|}{ Vice-Rector } \\
\hline Belgium & 1 & - & - & - & - \\
\hline China & 1 & - & - & - & - \\
\hline Switzerland & 4 & - & 1 & $27,27 \%$ & 3 out of 11 \\
\hline Finland & 1 & - & - & $50 \%$ & 2 out of 4 \\
\hline France & 2 & - & - & $27,27 \%$ & 3 out of 11 \\
\hline Germany & 2 & - & - & $33,33 \%$ & 2 out of 6 \\
\hline Israel & 2 & - & 1 & $40 \%$ & 2 out of 5 \\
\hline Norway & 1 & - & - & $66,67 \%$ & 2 out of 3 \\
\hline Netherlands & 1 & - & - & - & - \\
\hline Spain & 1 & - & - & $33,33 \%$ & 3 out of 9 \\
\hline UK & 10 & - & 2 & $22,81 \%$ & 13 out of 5 \\
\hline USA & 14 & 2 & 1 & $33,73 \%$ & 28 out of 8 \\
\hline Total & $\mathbf{4 0}$ & $\mathbf{2}$ & $\mathbf{5}$ & - & 58 \\
\hline
\end{tabular}

Source: adapted from the studies of European Commission - Special Eurobarometer 296 Discrimination in the European Union: Perceptions, Experiences and Attitudes

As far as the Romanian higher education environment is concerned, all 12 top Universities have male Rectors. Also, out of a number of 69 Deputy Deans, 54 are male (78.2\%) and 15 are females (21.7\%). We can see that, on an average, the ratio females - males holding the position of Deputy Dean is 1 to 4 in universities where both genders are present; there is no university where women in this position outnumber men, or where at least their number is equal.

Table 3: Females in leadership positions in the top 12 Romanian universities

\begin{tabular}{|c|l|l|l|l|l|}
\hline Ranking & \multicolumn{1}{|c|}{ University } & \multicolumn{1}{c|}{ President } & \multicolumn{1}{c|}{ Rector } & \multicolumn{2}{c|}{ Vice-Rector } \\
\hline $\mathbf{1}$ & University Politechnica of Bucharest & - & - & - & 1 out of 4 \\
\hline $\mathbf{2}$ & Alexandru Ioan Cuza University & - & - & - & 1 out of 7 \\
\hline $\mathbf{3}$ & $\begin{array}{l}\text { Bucharest Academy of Economic } \\
\text { Studies }\end{array}$ & - & - & $27,27 \%$ & 1 out of 6 \\
\hline $\mathbf{4}$ & University of Bucharest & - & - & $50 \%$ & 2 out of 5 \\
\hline $\mathbf{5}$ & $\begin{array}{l}\text { University of Medicine and Pharmacy } \\
\text { Iuliu Hatieganu Cluj Napoca }\end{array}$ & - & - & $27,27 \%$ & 1 out of 5 \\
\hline $\mathbf{6}$ & $\begin{array}{l}\text { Gheorghe Asachi Technical } \\
\text { University }\end{array}$ & - & $33,33 \%$ & 2 out of 6 \\
\hline
\end{tabular}




\begin{tabular}{|c|l|l|l|l|l|}
\hline $\mathbf{7}$ & University Politechnica of Timisoara & - & - & $40 \%$ & 0 out of 4 \\
\hline $\mathbf{8}$ & Dunarea de Jos University Galati & - & - & $66,67 \%$ & 3 out of 6 \\
\hline $\mathbf{9}$ & University of Craiova & - & - & - & 1 out of 6 \\
\hline $\mathbf{1 0}$ & West University of Timisoara & - & - & $33,33 \%$ & 0 out of 4 \\
\hline $\mathbf{1 1}$ & Technical University of Cluj Napoca & - & - & $22,81 \%$ & 1 out of 6 \\
\hline $\mathbf{1 2}$ & University Babes Bolyai & - & - & $33,73 \%$ & $\begin{array}{l}2 \text { out of } \\
10\end{array}$ \\
\hline
\end{tabular}

Source: authors' own survey

Things are similar at Faculty level: in the 120 sample faculties, out of 124 Deans, $79.03 \%$ are males and only $20.97 \%$ are females. The situation changes slightly for Deputy Deans, where females gain ground, representing $35 \%$ of the total number of people holding this position.

If we look at the profile of the sample Romanian universities, we can see that, for technical universities (which provide a wide range of faculties), the percentage of males occupying the position of Dean remains high $(84.1 \%$ and $84.62 \%$ respectively), while for medical and pharmaceutical universities, the situation is reversed. Things are similar for the Deputy Dean position, where faculties in technical universities present a high percentage of males $(78.41 \%$ and $64.41 \%$ respectively), while in medical and pharmaceutical faculties, females hold the majority of titles $(69.23 \%)$.

Therefore, we can say that women tend to occupy leadership positions in faculties of a "soft" nature, more than in those of exact sciences. Even so, their number is below that of men; the only domain where female Deans outnumber males is that of medical and pharmaceutical sciences.

Table 4: Gender distribution of Deans according to faculty type

\begin{tabular}{|c|c|c|c|}
\hline & \multirow[t]{2}{*}{ Faculty profile } & \multicolumn{2}{|c|}{ Gender distribution } \\
\hline & & Male (\%) & Female (\%) \\
\hline 1 & Economics and Business Administration & 9 & 4 \\
\hline 2 & Biology, Chemistry, Geography & 8 & 3 \\
\hline 3 & Law, History, Philosophy & 13 & - \\
\hline 4 & Physics & 3 & - \\
\hline 5 & Letters, Foreign Languages & 2 & 2 \\
\hline 6 & Mathematics, Informatics & 4 & - \\
\hline 7 & Psychology & 3 & - \\
\hline 8 & Television, Theatre & 1 & - \\
\hline 9 & Physical Education and Sports & 2 & - \\
\hline 10 & Agriculture & 3 & 2 \\
\hline 11 & Medicine, Pharmacy & 4 & 7 \\
\hline 12 & Technical sciences & 37 & 7 \\
\hline
\end{tabular}

Source: Authors' own survey

As the table shows, there are domains where there are no female Deans, such as: law, history and philosophy; mathematics, informatics; psychology, physics.

As to the gender distribution for the Deputy Dean position, things are similar, since only in the medical / pharmaceutical domain women outnumber men; for the faculties in the area of business administration, economics and psychology, the numbers of men and women are equal. A huge discrepancy between the two categories can be found in domains such as law, philosophy and history, where there are twenty men and only 6 women, and, as was to be expected, in the technical domain, where the ratio is $16: 69$. 
Table 5: Gender distribution of Deputy Deans according to faculty type

\begin{tabular}{|r|l|c|c|}
\hline \multirow{2}{*}{ Faculty profile } & \multicolumn{2}{c|}{ Gender distribution } \\
\cline { 3 - 4 } & & Male (\%) & Female (\%) \\
\hline $\mathbf{1}$ & Economics and Business Administration & 1 & 6 \\
\hline $\mathbf{2}$ & Biology, Chemistry, Geography & 13 & 6 \\
\hline $\mathbf{3}$ & Law, History, Philosophy & 20 & 6 \\
\hline $\mathbf{4}$ & Physics & 3 & - \\
\hline $\mathbf{5}$ & Letters, foreign languages & 6 & 7 \\
\hline $\mathbf{6}$ & Mathematics, Informatics & 5 & 1 \\
\hline $\mathbf{7}$ & Psychology & 1 & 3 \\
\hline $\mathbf{8}$ & Television, Theatre & 1 & - \\
\hline $\mathbf{9}$ & Physical Education and Sports & 3 & 1 \\
\hline $\mathbf{1 0}$ & Agriculture & 9 & 6 \\
\hline $\mathbf{1 1}$ & Medicine, Pharmacy & 4 & 9 \\
\hline $\mathbf{1 2}$ & Technical & 69 & 16 \\
\hline
\end{tabular}

Source: Authors' own survey

The figures continue to track the strong correlation between the Romanian's gender gap and its national competitiveness, income and development. Country's competitiveness depends on its human talent-the skills, education and productivity of its workforce. Because women account for one-half of a country's potential talent base, a nation's competitiveness in the long term depends significantly on whether and how it educates and utilizes its women.

\section{Qualitative Analysis}

The results obtained from the qualitative analysis show that, in general, the respondents did not feel that they had been discriminated against on the basis of gender, as the university is considering an environment where something like this is not likely to happen. People working in a university are perceived as much more open, part of a system which, sooner or later, still facilitates promotion. However, most interviewed people have admitted that women have to put in more effort to prove their abilities, they have to show a stronger commitment, and this may be difficult since they have to devote a lot of time to their position.

Our aim was to focus on whether the gap between women and men in the chosen variables has declined, rather than whether women are "winning" the "battle of the sexes". (Global Gender Gap, 2102)
Most of the respondents are holding a leadership position for the first time in their career $(6$ are in this situation, out of which 3 have been elected and 3 have been appointed), although two of them have been holding this position for 8 years. The other four females who have agreed to be interviewed have over 12 years seniority in leadership positions, having held various titles prior to this interview (at departmental, faculty or university level).

As was to be expected, the difficulty of being in a leadership position does not come from carrying out the respective tasks or from a lack of qualities on the part of women; the difficulty stems from the need to allocate time to carry out the tasks. If three people claim that they do not encounter special difficulties, the other 7 claim that these leadership positions imply a prolonged schedule, long administrative meetings which sometimes are not very efficient, extra working hours regardless of day or time, frequent trips over several days. Thus, it becomes difficult to prioritize activities, especially when family responsibilities are in the way, or when one has to carry out educational and research activities, which leaves less time for leadership (Manolescu et al.,2012).

As to the question about the obstacles that women, unlike men, come across when they hold a management position, the conclusion was that there are no specific barriers. However, there are 4 people who have claimed 
the opposite, stating that it is more difficult for women to be remarked in a men's world, with a male culture, characterized by fierce competition (this also emerged as a result of investigating specialized literature). Since it is necessary to belong to an advocacy group or a lobby in order to carry out the duties of a management position, women also face difficulties in being informed about the existence of research projects, the participation in meetings, opportunities for publication etc, and also in receiving this information in due time. (Gatrell, C. and Cooper,C. 2007)

All these difficulties, as well as the selfimposed barriers, may represent reasons why women do not wish to occupy a management position. In fact, there have been two people out of ten who have maintained that their own barriers and personal prejudices or the influence of family and friends and selfsufficiency are the factors that render the number of women in leadership positions in universities smaller than that of men. In close connection to the barriers and prejudices mentioned above, there also appear reasons such as: difficulty in controlling interest groups, difficulty in persuading a critical mass or directing one's energy towards other types of activities, such as creative or family-related ones.

In fact, when the question "Why are there fewer women in leadership positions than men?" was asked, most interviewed people claimed that there is the possibility that women may not be interested in these positions; the opinion also presented itself that this criterion (related to women in leadership positions) cannot be relevant when discussing gender equality and equality of opportunities. Other people stated that, sometimes, the managerial career of women may be shorter, and there may exist a tendency on their part to step down after one term of office, due to the encountered difficulties and in favour of their academic / research career. Also, it is possible that females may not run for office because they are not emotionally and managerially trained to carry out their tasks.

Respondents unanimously consider that universities provide equal chances and that there are no discrimination issues, either in the faculties and universities they work for or in other universities in the country they have collaborated with. Consequently, most people believe that no measures are necessary to ensure equality of opportunities, so as not to come to a positive discrimination of women in this respect.

\section{Conclusion}

The qualitative study performed on a relevant number of universities has proved that, both at national and international level, the number of women in leadership positions is considerably smaller than the number of men. Moreover, the positions women hold are, in most cases, restricted to some domains or hierarchically inferior (at faculty or departmental level). We believe that this indicator (the number of women in leadership positions), although considered by some researchers irrelevant to the study of equal opportunities, makes us look into the reasons why females do not enjoy greater representation, an issue that has also been shown by the qualitative research in the present paper.

Thus, the qualitative research shows that the existing situation is not caused by discrimination; it is rather circumstantial in nature (triggered by prioritising personal objectives or pressures from outside the professional life). We have therefore found that women in leadership positions also come across specific barriers related mostly to the prolonged working schedule, which involves a great and constant effort. This makes it difficult to strike a balance between administrative, didactic/research and personal, family-related tasks.

The recommended measures above seem to pertain to the unwritten policies. Among the actions and measures that ought to be implemented at a local level, in universities, we feel that the following are appropriate (Gender Equality Action Plan 2010 - 2012):

Position plans must be drawn up for the entire strategy period until 2020 for announcements and recruitment to permanent academic positions, based on expected departures and the gender composition of academic environments, and the recruitment base. This particularly applies to academic environments 
with a low share of female employees and/or under representation of women, in relation to the recruitment base.

Academic positions must normally be announced as an associate professor to ensure a wide range of applicants and effective new hiring. Special reasons must be given for the announcement of professorships.

- Use "search committees" for all announcements of permanent academic positions and academic management positions to identify and recruit relevant national and international female applicants.

Motivate and actively facilitate conditions for women holding the position of associate professor who want to qualify as a professor.

- $\quad$ Motivate and facilitate conditions for women who want to qualify for permanent positions.

Ensure that the gender equality aspect is taken into consideration when making decisions regarding research strategy

If only these few recommendations were to be taken into account, the following targets ought to be attained in the ensuing 10 years:

- The percentage of women among permanent academic staff should go up by $40 \%$;

The percentage of women with the rank of associate professor should go up by $20 \%$;

The percentage of women in academic management positions should increase.

- $\quad$ The percentage of women who qualify as a professor should increase.

\section{References}

1. Bagihole B. (2002) - Academia and the reproduction of unequal opportunities for women, Science Studies, Vol 15, No 1, pp.46-60

2. Doherty L., Manfredi S. (2006). Women's progression to senior positions in English universities, Employee relations, Vol 28, No 6, pp. 553-572

3. Duehr, E., Bono J. (2006). Men, women and managers: Are stereotypes finally changing? Personnel Psychology 59 (4):815-846, http://onlinelibrary.wiley.com/doi/10.1111/j. 1744-6570.2006.00055.x/pdf.

4. Eagly, A., Carli L. (2007). Through the labyrnith: the truth about how women become leaders. Boston, Massachussets: Harvard Business School Press; https://nclp.umd.edu/resources/bookreviews /BookReview-Through_the_Labyrinth-Baruch2011.pdf

5. European Commission (2010). Europe 2020 - A strategy for smart, sustainable and inclusive growth, Brussels, 03.03.2010,

6. http://eur-

lex.europa.eu/LexUriServ/LexUriServ.do?uri= CELEX:52010DC2020:en:NOT

7. Gatrell, C, and C Cooper. (2007). "No cracks in the glass ceiling: women managers, stress and the barriers to success " In Handbook on Women in Business and Management, edited by D. Bilimoria and K. Piderit. Cheltenham: Edward Elgar, pp. 119

8. Haussman, R; Tyson L.; Zahidi, S (2012). "The Global Gender Gap Report", World Economic Forum, p. 11-23

9. Hopkins, M, and D O'Neil. (2007) - "Women and success: dilemmas and opportunities", In Handbook on Women in Business and Management, edited by D. Bilimoria and K. Piderit. Cheltenham: Edward Elgar.

10.Ilie, A.G., Sârbu, R. (2011) - "Sustainable succes in Higher Education by sharing the best practices as a result of benchmarking process", Amfiteatrul economic, No 5, Edited by ASE, p.688-697

11. Manolescu, I.T., Mutiu O., Lungu C. (2012) "Gender equality in accessing leadership positions in universities", Alexandru Ioan Cuza University, Iasi, pp.40-60

12. Miller-Friedman J., Sonnert G. Sadler P. (2011) - "Bridging the gender gap: Eqality vs. 
Equity", http://ww.clemson.edu/ese/per/wpcontent/t hemes/gallery/gallery/images/publication

13.0'Neil, D. A., Hopkins, M. M., Bilimoria, D. (2008) - "Women's Careers at the Start of the 21st Century: Patterns and Paradoxes ", Journal of Business Ethics, 4 ed., vol. 80, pp.727-743.

14.Rosca, G, Sarbu, R., Ilie A.G. (2010) - "The evaluation of the professors' quality in the Bucharest academy of economic studies (baes) effectiveness and efficiency", Qality Management in Higher Education, Tulcea, pp 235-238

15.Sârbu, R., Ilie, A.G.,Dumitriu D., Enache A. C. (2011) - "The Quality of Educational Services in Higher Education - Assurance, Management or Excelence ?", Amfiteatrul Economic vol. XI, No. 26, Edited by ASE, pp. 383-393

16.Tomas M., Lavie J.M., Duran M. (2010)

"Women in academic administration at the university". Educational Management Administration\&Leadership, Vol 38, No 4, pp 487-498

17.Umbach P (2007) - "Gender equity in the academic labor market: an analysis of academic disciplines", Research in Higher Education, Vol 48, No 2, pp 169-192

18.University of Oslo (2013) - "Gender Equality Action Plan 2010 - 2012", http://www.uio.no/english/about/strategy/a ction-plan-gender-equality-2010-2012.pdf

19.Ward K., Wolf-Wendel L. (2004). "Academic motherhood: managing complex roles in research university". The Review of Higher Education, Vol 27, No 2, pp. 233-257

20.Wolf-Wendel L, Ward .K (2006) - "Academic life and motherhood: variations by institutional type", Higher Education, Vol 52, pp 487-521 